\title{
Carbon and nutrient stocks in roots of forests at different altitudes in the Ecuadorian Andes
}

\author{
Nathalie Soethe*1, Johannes Lehmann $\dagger$ and Christof Engels* \\ * Department of Plant Nutrition and Fertilization, Humboldt University of Berlin, Albrecht Thaer Weg 4, 14195 Berlin, Germany \\ $\dagger$ Department of Crop and Soil Sciences, Cornell University, USA \\ (Accepted 15 December 2006)
}

\begin{abstract}
Carbon and nutrient stocks in below-ground biomass have rarely been investigated in tropical montane forests. In the present study, the amounts of carbon, nitrogen, phosphorus, sulphur, potassium, calcium and magnesium in root biomass were determined by soil coring and nutrient analysis in forests at three altitudes (1900, 2400 and $3000 \mathrm{~m}$ ) in the Ecuadorian Andes. Root biomass increased markedly from $2.8 \mathrm{~kg} \mathrm{~m}^{-2}$ at $1900 \mathrm{~m}$ and $4.0 \mathrm{~kg} \mathrm{~m}^{-2}$ at 2400 to $6.8 \mathrm{~kg} \mathrm{~m}^{-2}$ at $3000 \mathrm{~m}$. The contribution of coarse roots ( $>2 \mathrm{~mm}$ in diameter) to total root biomass increased from about $70 \%$ at $1900 \mathrm{~m}$ to about $80 \%$ at higher altitudes. In fine roots ( $\leq 2 \mathrm{~mm}$ in diameter), concentrations of nutrients except calcium markedly decreased with altitude. Therefore, the nutrient stocks in fine roots were similar at $1900 \mathrm{~m}$ and $3000 \mathrm{~m}$ for nitrogen and sulphur, and were even lower at higher altitudes for phosphorus, potassium and magnesium. In coarse roots of Graffenrieda emarginata concentrations of nutrients were substantially lower than in fine roots, and were little affected by altitude. The data suggest that the importance of coarse roots for long-term carbon and nutrient accumulation in total plant biomass increases with increasing altitude.
\end{abstract}

Key Words: Biomass, carbon sequestration, diameter, fine roots, immobilization, montane forests, nutrient cycling

\section{INTRODUCTION}

In the debate about the global carbon cycle the role of forest biomes as potential carbon sources and sinks receives increasing attention (Clark 2002, 2004; Fehse et al. 2002, Malhi et al. 1999). Considerable amounts of terrestrial $\mathrm{C}$ are sequestered in tropical forests (Malhi et al. 1999, Vogt et al. 1996). In 1994, these forests contributed $37 \%$ of total $C$ sequestered worldwide in forest ecosystems. About $50 \%$ of total $\mathrm{C}$ in tropical forests is bound in biomass (Dixon et al. 1994). Roots contribute $7-34 \%$ to total biomass in tropical lowland forest ecosystems (Vogt et al. 1996). Thus, C stocks in root systems of tropical lowland forests are important components of the $\mathrm{C}$ budget on a global scale.

Within forest biomes, roots have a large impact on C and nutrient fluxes (Chen et al. 2001, Ostertag \& Hobbie 1999). Here, the amounts of $C$ and nutrients returned to soil from fine-root turnover may equal or exceed that from leaf litter (Joslin \& Henderson 1987, Raich \& Nadelhoffer 1989). Besides root tissue composition

\footnotetext{
${ }^{1}$ Corresponding author. Email: Nathalie.Soethe@agrar.hu-berlin.de
}

and various environmental factors, root diameter is a key factor that governs the nutrient return to soil via root turnover (Janisch et al. 2005, McClaughtery et al. 1982, Nambiar 1987, Ostertag \& Hobbie 1999). Nambiar (1987) reported that root turnover of Pinus radiata is largely confined to roots $<1 \mathrm{~mm}$ in diameter.

On the other hand root biomass contributes to nutrient immobilization and may thus diminish nutrient losses from the ecosystem by leaching. This is especially true for tropical lowland forests with high precipitation rates where most potassium $(\mathrm{K})$ and calcium $(\mathrm{Ca})$ are stored in biomass, whereas the soil is often impoverished in these nutrients (Jordan 1985).

Data on total below-ground biomass as well as $\mathrm{C}$ and nutrients in below-ground biomass of tropical montane forests are scarce (Edwards \& Grubb 1977, 1982; Ostertag 2001, Priess et al. 1999, Vance \& Nadkarni 1992). Tropical montane forests are characterized by high spatial heterogeneity in climatic conditions. Usually with increasing altitude temperatures decrease while precipitation increases, causing a decrease in mineralization rates (Fabian et al. 2005, Holder 2003, Marrs et al. 1988). As a result, the amounts of C stored in the organic layer and mineral soil of montane regions are 
usually higher than in the lowlands (Edwards \& Grubb 1977). It is also likely that the amounts of $C$ and nutrients in below-ground biomass may be affected by the climatic changes along altitudinal gradients.

Nutrient stocks in the root biomass are dependent on nutrient concentrations in root tissue. These concentrations are governed by several internal and external factors. The impact of different diameter classes of tree roots on nutrient concentration is well documented. Concentrations of $\mathrm{N}$ and $\mathrm{P}$ generally decrease with increasing root diameter, while no consistent pattern has been found for $\mathrm{Ca}, \mathrm{Mg}$ and $\mathrm{K}$ concentrations (Edwards \& Grubb 1982, Gordon \& Jackson 2000, John et al. 2002, Klinge 1975, Nambiar 1987). Furthermore it was shown that in forest ecosystems nutrient concentrations in fine roots are influenced by season (Guevara \& Romero 2004), soil age (Ostertag \& Hobbie 1999), stand age (Meier et al. 1985) and stand density (Barron-Gafford et al. 2003). In many cases an increase in root nutrient concentrations is explained by an increase in soil nutrient availability (Hendricks et al. 2000, Ostertag \& Hobbie 1999, Yin \& Perry 1991).

In this study, we measured $C$ and nutrient stocks in roots differing in diameter. We use the term 'nutrient' for the nutrient elements $\mathrm{N}, \mathrm{S}, \mathrm{P}, \mathrm{K}, \mathrm{Ca}$ and $\mathrm{Mg}$, and the term 'element' to encompass nutrients as well as C. It may be expected that nutrient stocks in fine roots constitute a significant source of nutrient supply for plants via fineroot turnover, whereas $\mathrm{C}$ and nutrient stocks in coarse roots contribute to long-term sequestration of elements in plant biomass. The investigation was performed in tropical montane forest in Ecuador at 1900, 2400 and $3000 \mathrm{~m}$. We hypothesized that root biomass and root $\mathrm{C}$ and nutrient stocks increase with altitude because nutrient limitation of plant growth increases biomass and nutrient partitioning to roots.

\section{STUDY SITES}

We selected three stands in an Ecuadorian tropical montane forest close to the provincial capital Loja. The lower stands $\left(1900 \mathrm{~m}, \mathrm{~S} 03^{\circ} 58^{\prime} \mathrm{W} 79^{\circ} 04^{\prime}\right.$, and $2400 \mathrm{~m}$, $\mathrm{S} 03^{\circ} 59^{\prime} \mathrm{W} 79^{\circ} 04^{\prime}$ ) were situated in the Reserva San Francisco at the northern fringes of the Podocarpus National Park that protects typical mountain ecosystems of southern Ecuador. The highest stand $\left(3000 \mathrm{~m}, \mathrm{~S} 04^{\circ} 06^{\prime}\right.$ W $79^{\circ} 10^{\prime}$ ) was located in the Cajanuma area in the northwestern edge of the National Park.

The three sites were situated on slopes similar in inclination $\left(31^{\circ}\right.$ at $1900 \mathrm{~m}, 28^{\circ}$ at $2400 \mathrm{~m}$, and $27^{\circ}$ at $3000 \mathrm{~m}$ ) and were exposed north-east or northwest. All stands were old-growth forests. Precipitation was markedly lower at $1900 \mathrm{~m}\left(1950 \mathrm{~mm} \mathrm{y}^{-1}\right)$ than at $2400 \mathrm{~m}\left(5000 \mathrm{~mm} \mathrm{y}^{-1}\right)$ and $3000 \mathrm{~m}(4500 \mathrm{~mm}$ $\left.\mathrm{y}^{-1}\right)$. Mean annual temperature decreased from $1900 \mathrm{~m}$ $\left(14.9{ }^{\circ} \mathrm{C}\right)$ to $2400 \mathrm{~m}\left(12.3{ }^{\circ} \mathrm{C}\right)$ and $3000 \mathrm{~m}\left(8.6{ }^{\circ} \mathrm{C}\right)$ (Röderstein et al. 2005). Soils at $1900 \mathrm{~m}$ and $2400 \mathrm{~m}$ were classified at gleyic Cambisols, soils at $3000 \mathrm{~m}$ were mainly Podzols (S. Iost, pers. comm.). Soils were acid $\left(\mathrm{pH}_{\left(\mathrm{CaCl}_{2}\right)}<3.5\right.$ to a depth of $0.3 \mathrm{~m}$ in mineral soil $)$ and covered by organic layers that were deeper at $3000 \mathrm{~m}$ (an average of $0.31 \mathrm{~m}$ ) than at 1900 and $2400 \mathrm{~m}$ (an average of $0.15 \mathrm{~m}$ and $0.16 \mathrm{~m}$, respectively). Maximum tree height decreased from 1900 to 2400 and $3000 \mathrm{~m}$ $(19,12$ and $9 \mathrm{~m}$, respectively). Further information on plant species composition that changed considerably with altitude, is given in Röderstein et al. (2005).

\section{METHODS}

\section{Sampling of roots $\leq 5 \mathrm{~mm}$ in diameter}

Sampling of roots $\leq 5 \mathrm{~mm}$ in diameter was conducted during the dry season of November/December 2001. At each altitude, one $20 \times 20-\mathrm{m}$ plot in the closed forest was established. Samples were taken from 20 randomly distributed locations. From each location, a sample of $100 \times 100 \mathrm{~mm}$ was taken in vertical direction from the organic layer. Mineral soil was sampled vertically with a soil corer $(80 \mathrm{~mm}$ in diameter) at depths of $0.0-0.1 \mathrm{~m}$, $0.1-0.3 \mathrm{~m}, 0.3-0.5 \mathrm{~m}, 0.5-0.7 \mathrm{~m}, 0.7-0.9 \mathrm{~m}$ and $0.9-$ $1.1 \mathrm{~m}$. When parent soil material was reached above $1.1 \mathrm{~m}$, sampling was finished earlier.

\section{Sampling of roots $>5 \mathrm{~mm}$ in diameter}

Sampling of roots $>5 \mathrm{~mm}$ in diameter was conducted in the dry season from December 2002 until January 2003. Since the sampling procedure was very destructive and the $20 \times 20$-m plots had to be maintained for further investigations, sampling was performed on 15 randomly distributed locations around the plots. Both soil properties and vegetation around the plots were similar to those within the plots (unpubl. data), allowing a comparison of roots smaller than and larger than $5 \mathrm{~mm}$ in diameter. At each of the 15 sampling locations a hole of $0.4 \times 0.4 \mathrm{~m}$ was dug in a vertical direction. Roots within the hole were cut or sawn off and separated into roots from the organic layer, and from $0.0-0.1$ and $0.1-0.3 \mathrm{~m}$ depths of mineral soil. In soil layers deeper than $0.3 \mathrm{~m}$ no coarse roots were found. Roots that grew at the interface between organic layer and mineral soil were added to the roots from the organic layer.

\section{Analysis of roots $\leq 5 \mathrm{~mm}$ in diameter}

For determination of root biomass, roots were sorted out from a subsample of $20-50 \mathrm{~g}$ (organic layer) or 
100-200 g (mineral soil) of each sample. For washing of each subsample, a 0.6-mm-mesh sieve was used. From a small bowl filled with water, roots and remaining soil residue were separated with forceps. Under a binocular microscope living and dead roots were separated by colour, root elasticity and the degree of cohesion of cortex, periderm and stele (Persson 1978). Living roots were separated into the diameter classes $\leq 1 \mathrm{~mm},>1-$ $2 \mathrm{~mm},>2-5 \mathrm{~mm}$. Following Röderstein et al. (2005) who determined fine-root turnover at the same study sites, root $\leq 2 \mathrm{~mm}$ were classified as fine roots, whereas roots $>2-5 \mathrm{~mm}$ were included to the coarse root fraction. Roots were deep frozen for storage to allow further analysis in Germany. Afterwards, roots were dried at $50^{\circ} \mathrm{C}$ for $24 \mathrm{~h}$ and weighed.

For the analysis of elemental composition, additional root material was sorted out from the remaining soil material of every sample. After washing, roots were sorted out directly from the mesh. This procedure allowed a shorter contact of the roots with water and a collection of sufficient root material for nutrient analysis. In a preceding analysis it was shown that this procedure was associated with negligible losses of nutrients during sample preparation (unpubl. data). Roots for nutrient analysis were separated into the same diameter classes as described above, dried at $50{ }^{\circ} \mathrm{C}$ for $24 \mathrm{~h}$ and ground with a flint mill (Type MM2, Retsch-GmbH \& CoKG, Haan). Concentrations of $\mathrm{C}, \mathrm{N}$ and $\mathrm{S}$ were determined with a CNS analyser (Vario Max CNS, elementar Analysesysteme, Hanau). For determination of $\mathrm{P}, \mathrm{K}, \mathrm{Ca}$ and $\mathrm{Mg}$, ground samples were digested with concentrated $\mathrm{HNO}_{3}$ under pressure (Heinrichs et al. 1986). Concentrations of K, $\mathrm{Ca}$ and $\mathrm{Mg}$ were measured by flame atomic absorption spectrometry (Perkin Elmer 4100, Perkin Elmer, Milano) and $\mathrm{P}$ concentrations were assessed with a spectral photometer (Specord 200, Analytik Jena, Jena) using the molybdenum blue procedure (Murphy \& Riley 1962).

\section{Analysis of roots $>5 \mathrm{~mm}$ in diameter}

For determination of coarse root mass, roots from each soil layer were separated into the diameter classes $>5$ $10 \mathrm{~mm},>10-20 \mathrm{~mm},>20-50 \mathrm{~mm}$ and $>50 \mathrm{~mm}$. Root samples were dried at $50{ }^{\circ} \mathrm{C}$ until constant weight was achieved. Carbon and nutrient concentrations in coarse roots were assessed only from Graffenrieda emarginata (Ruiz \& Pav.) Triana (Melastomataceae). This species occurs at $1900-2400 \mathrm{~m}$ altitude, and contributes up to $11 \%$ to total tree basal area (J. Homeier, pers. comm.). Samples were obtained from the stands at 1900 and $2400 \mathrm{~m}$, from three trees per altitude. Roots of each tree were divided in the same diameter classes as described above without considering soil depth. Subsamples of about $20 \mathrm{~g}$ were taken from every diameter class.
Therefore smaller coarse roots were reduced to small pieces with help of a hedge clipper. From thicker coarse roots, representative subsamples from the bark to the root centre were taken with a borer. Carbon and nutrient analyses from these subsamples were performed as described above.

\section{Determination of soil C stocks}

Soil C stocks were determined from the 20 replicate soil cores per altitude and soil depth taken for determination of root biomass $\leq 5 \mathrm{~mm}$ in diameter. Therefore, four equal subsamples of the 20 replicates were bulked together in each case to obtain five replicate samples per soil depth for analysis. Samples were air dried for storage. Concentrations of total $\mathrm{C}$ were assessed with a CNS analyser (Vario Max CNS, Elementar Analysesysteme, Hanau). Carbon stocks in fine-root biomass were subtracted from these data to obtain $\mathrm{C}$ stocks in rootless soil material.

\section{Statistical analysis}

Statistical analyses were performed with help of the SPSS 13.0 software. As an exception, posthoc-tests for the nonparametric Kruskal-Wallis test (Dunn test and Nemenyi test) were calculated manually.

Root biomasses at different altitudes within one soil depth were compared by Kruskal-Wallis test for nonnormally distributed replicates and subsequent Dunn test for unequal numbers of replicates (roots $\leq 5 \mathrm{~mm}$ in diameter) or Nemenyi test for equal numbers of replicates (roots $>5 \mathrm{~mm}$ in diameter).

Nutrients stocks in different root diameter classes $\leq 5 \mathrm{~mm}$ were calculated from the average root biomass of the respective diameter class and the replicate nutrient concentrations within this diameter class. ANOVA and Tukey test or t-test were used to assess significant differences in total fine- and coarse-root biomass, nutrient stocks or nutrient concentrations between altitudes or between diameter classes. Additionally, two-way ANOVA was applied to nutrient concentrations in roots to compare the impact of altitude and diameter class. Data were logtransformed when necessary.

\section{RESULTS}

\section{Root biomass}

Total root biomass steadily increased from 1900 to $3000 \mathrm{~m}$ (Table 1). At $3000 \mathrm{~m}$, biomass of fine roots and coarse roots was significantly higher than at 2400 and $1900 \mathrm{~m}$. The fraction of fine roots in total root biomass 
Table 1. Root biomass $\left(\mathrm{g} \mathrm{m}^{-2}\right)$ at different altitudes $(\mathrm{n}=20$ for fine roots $\leq 2 \mathrm{~mm}$ in diameter, $\mathrm{n}=15$ for coarse roots $>2 \mathrm{~mm}$ in diameter) of Ecuadorian montane forests. Data shown are mean \pm SE. Different lowercase letters indicate significant differences between altitudes (Tukey test, $\mathrm{P}<0.05)$.

\begin{tabular}{|c|c|c|c|c|}
\hline $\begin{array}{l}\text { Altitude } \\
\quad(\mathrm{m})\end{array}$ & $\begin{array}{l}\text { Fine-root biomass } \\
\qquad\left(\mathrm{g} \mathrm{m}^{-2}\right)\end{array}$ & $\begin{array}{l}\text { Coarse-root biomass } \\
\left(\mathrm{g} \mathrm{m}^{-2}\right)\end{array}$ & $\begin{array}{l}\text { Total root biomass } \\
\left(\mathrm{g} \mathrm{m}^{-2}\right)\end{array}$ & $\begin{array}{l}\text { Proportion of root biomass } \\
\text { in total biomass }{ }^{1}(\%)\end{array}$ \\
\hline 1900 & $890 \pm 70^{\mathrm{a}}$ & $1910 \pm 264^{\mathrm{a}}$ & 2800 & 14 \\
\hline 2400 & $729 \pm 90^{\mathrm{a}}$ & $3286 \pm 567^{\mathrm{a}}$ & 4015 & 29 \\
\hline 3000 & $1503 \pm 127^{\mathrm{b}}$ & $5340 \pm 473^{\mathrm{b}}$ & 6843 & 38 \\
\hline
\end{tabular}

${ }^{1}$ Data on above-ground biomass were derived from G. Moser (pers. comm.).

decreased from $32 \%$ at $1900 \mathrm{~m}$ to $18 \%$ at $2400 \mathrm{~m}$ and $22 \%$ at $3000 \mathrm{~m}$. In contrast to root biomass, aboveground biomass as estimated from dbh, tree height and wood density (Chave et al. 2005) decreased with increasing altitude (G. Moser, C. Leuschner and D. Hertel, unpubl. data). Correspondingly, the proportion of root biomass in total biomass strongly increased with increasing altitude (Table 1).

At all altitudes, the largest proportion of root biomass was located in the organic layer (Figure 1). This was most pronounced at $3000 \mathrm{~m}$ and $2400 \mathrm{~m}$, where about $80 \%$ of total root biomass was located in this layer, in contrast to about $59 \%$ at $1900 \mathrm{~m}$. Below $0.1 \mathrm{~m}$ depth of mineral soil, about $10 \%$ of total coarse-root and $38 \%$ of total fine-root biomass were found at $1900 \mathrm{~m}$, compared with only $1 \%$ of total coarse-root and about $6 \%$ of total fine-root biomass at 2400 and $3000 \mathrm{~m}$. This indicates that nutrient cycling between plant roots and soil via fine roots and, in the long term, release of $\mathrm{C}$ and nutrients into the soil by decaying coarse roots, are mainly confined to the uppermost soil layers, particularly at high altitudes.

\section{Element concentrations in roots}

The element concentrations of roots $\leq 5 \mathrm{~mm}$ in diameter were not affected by the soil layer or soil depth (data not shown). Thus, only element concentrations in roots from the organic layer are shown in this study. The root concentrations of elements with the exception of Ca were significantly $(\mathrm{P}<0.05)$ influenced by altitude (Table 2$)$, showing strong decreases (40-60\%) of N, S, P, K and $\mathrm{Mg}$ from $1900 \mathrm{~m}$ to $3000 \mathrm{~m}$ (Table 3). Furthermore, the root concentrations of elements with the exception of $\mathrm{Mg}$ were significantly influenced by root diameter (Table 2) showing marked decreases in the concentrations of $\mathrm{N}, \mathrm{S}$ and $\mathrm{P}$ and marked increases in the concentrations of $\mathrm{K}$ and $\mathrm{Ca}$ with increasing root diameter (Table 3).

The concentrations in roots $>5 \mathrm{~mm}$, which were only measured in G. emarginata, with the exception of Ca were not significantly influenced by altitude (Table 4). The Ca concentrations were higher at $2400 \mathrm{~m}$ than at $1900 \mathrm{~m}$ (Table 5). Increasing coarse-root diameter significantly decreased the concentrations of $\mathrm{N}, \mathrm{S}$ and $\mathrm{P}$ (Table 4 and 5).

The concentrations of $\mathrm{N}, \mathrm{S}, \mathrm{P}$ and $\mathrm{Mg}$ in coarse roots $>5 \mathrm{~mm}$ of G. emarginata were markedly lower than concentrations of these elements in roots $\leq 5 \mathrm{~mm}$ that were bulked from all species growing in the forests stands (cf. Tables 3 and 5). Concentrations of $\mathrm{C}$ and $\mathrm{K}$ did not strongly vary between these root pools, whereas Ca concentrations were substantially higher in roots $>5 \mathrm{~mm}$ than in roots with smaller diameter.

\section{Stocks of carbon and nutrients in root biomass}

In fine roots up to $2 \mathrm{~mm}$ in diameter, stocks of all elements except $\mathrm{Ca}$ were significantly influenced by altitude (Table 6). Element stocks in fine roots were lowest at $2400 \mathrm{~m}$, i.e. at the altitude, where lowest fine-root biomass was associated with intermediate element concentrations (Table 3). Highest $\mathrm{P}$ and $\mathrm{K}$ stocks were observed at $1900 \mathrm{~m}$ because of high concentrations of these nutrients at this altitude. The stocks of $\mathrm{N}, \mathrm{S}$ and $\mathrm{Mg}$ were not significantly different between $3000 \mathrm{~m}$ and $1900 \mathrm{~m}$.

To obtain a rough estimate of element stocks in coarse roots $>2 \mathrm{~mm}$ in diameter, coarse root biomass of forest stands was multiplied with average element concentrations from $1900 \mathrm{~m}$ and $2400 \mathrm{~m}$ measured in coarse roots of $G$. emarginata. To obtain a rough estimate of element stocks in total root biomass, measured element

Table 2. Significance levels for differences in root element concentrations ( $\leq 5 \mathrm{~mm}$ in diameter) from root diameter and altitude calculated by two-way ANOVA $(\mathrm{n}=5)$.

\begin{tabular}{lccccccc}
\hline & $\mathrm{C}$ & $\mathrm{N}$ & $\mathrm{S}$ & $\mathrm{P}$ & $\mathrm{K}$ & $\mathrm{Ca}$ & $\mathrm{Mg}$ \\
\hline Altitude & $<0.001$ & $<0.001$ & $<0.001$ & $<0.001$ & $<0.001$ & 0.175 & 0.001 \\
Diameter & 0.001 & $<0.001$ & $<0.001$ & $<0.001$ & $<0.001$ & 0.021 & 0.106 \\
\hline
\end{tabular}


(a)

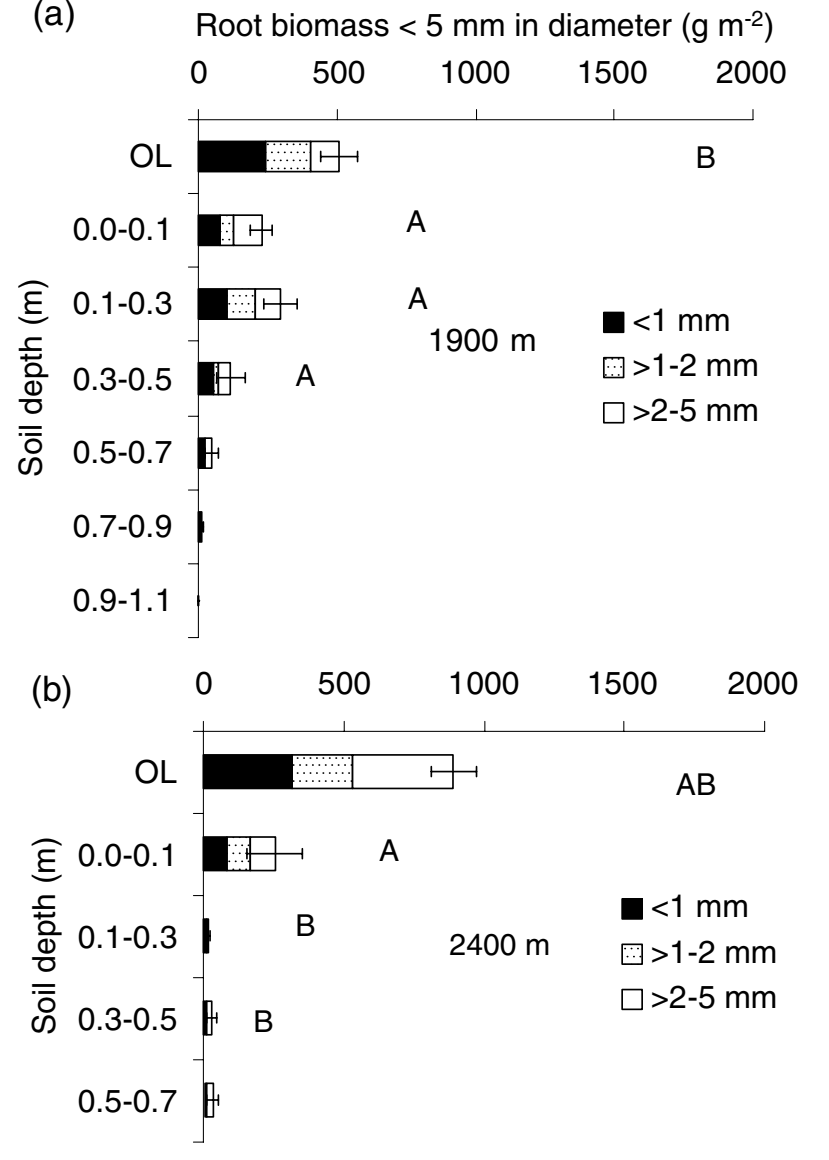

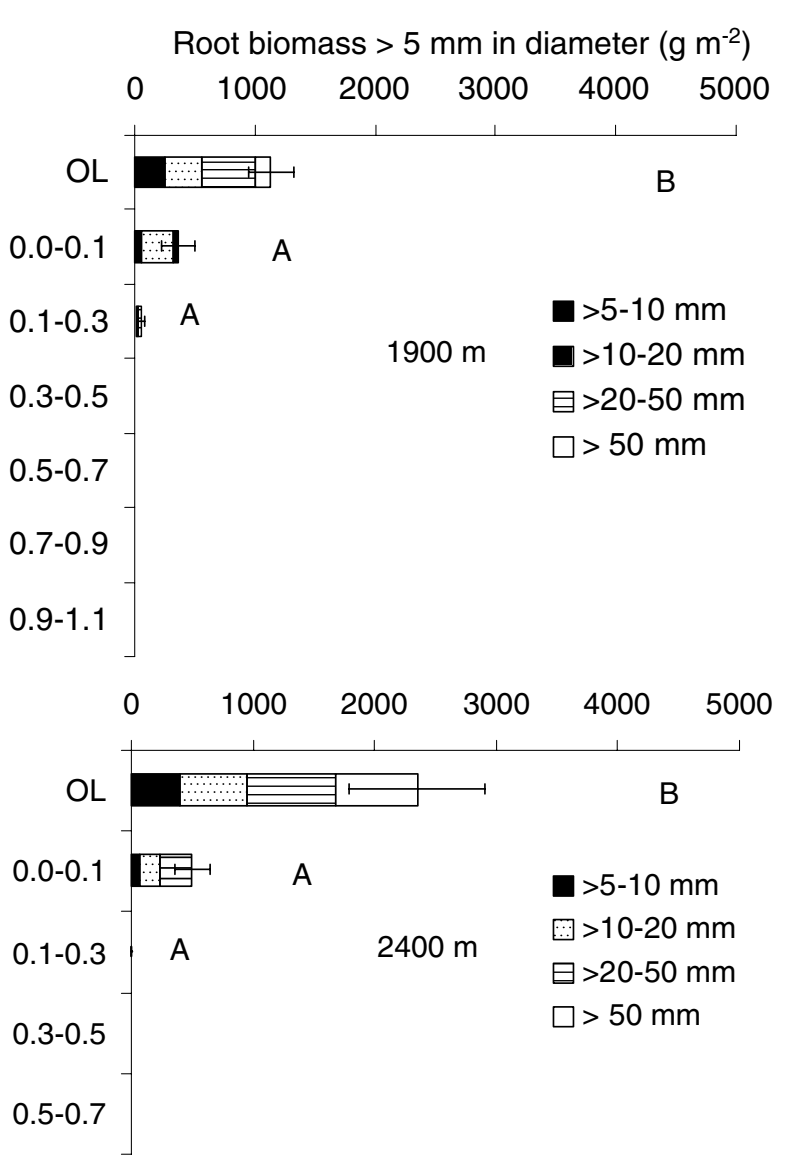
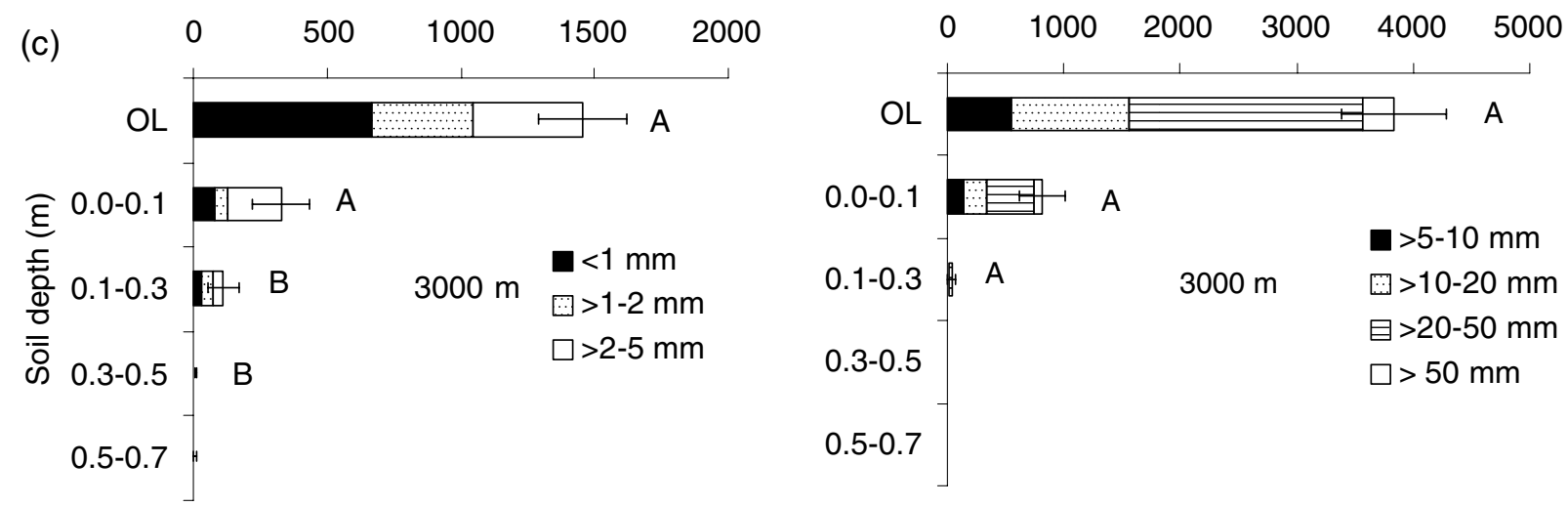

Figure 1 Root biomass $\left(\mathrm{g} \mathrm{m}^{-2}\right.$ ) of different diameter classes in different soil depths at (a) $1900 \mathrm{~m}$, (b) $2400 \mathrm{~m}$ and (c) 3000 m; OL=organic layer. Error bars indicate standard errors. Different upper-case letters indicate significant differences of root biomass between altitudes within one soil depth (root biomass $\leq 5 \mathrm{~mm}$ in diameter: $\mathrm{n}=9-20$, Dunn test, $\mathrm{P}<0.05$; root biomass $>5 \mathrm{~mm}$ in diameter: $\mathrm{n}=15$, Nemenyi test, $\mathrm{P}<0.05$ ).

stocks in fine roots and estimated element stocks in coarse roots were summed up. Element stocks in coarse root and total root biomass increased with altitude (Table 6). The only exception was the root stocks of $\mathrm{P}$ which were very similar at 1900 and $3000 \mathrm{~m}$.

Compared to data from literature, carbon stocks at $3000 \mathrm{~m}$ were about three times higher. At $3000 \mathrm{~m}$ also Ca stocks were substantially higher, whereas the stocks of all other elements in the present study were similar to the range found for the other tropical forests.

\section{Carbon stocks in soil}

Soil carbon stocks differed significantly between the sites at different altitudes (Table 7). Higher C stocks at 1900 and $3000 \mathrm{~m}$ than at $2400 \mathrm{~m}$ were the result of the 
Table 3. Element concentrations $\left(\mathrm{mg} \mathrm{g}^{-1}\right)$ in roots $\leq 5 \mathrm{~mm}$ in diameter $(\mathrm{n}=5)$ at different altitudes of Ecuadorian montane forests. Data shown are mean \pm SE.

\begin{tabular}{|c|c|c|c|c|c|}
\hline \multirow[b]{2}{*}{ Element } & \multirow{2}{*}{$\begin{array}{l}\text { Altitude } \\
(\mathrm{m})\end{array}$} & \multicolumn{4}{|c|}{ Diameter class $(\mathrm{mm})$} \\
\hline & & $\leq 1$ & $>1-2$ & $>2-5$ & Mean $^{1}$ \\
\hline \multirow[t]{3}{*}{$\mathrm{C}$} & 1900 & $500 \pm 3$ & $504 \pm 5$ & $500 \pm 2$ & $501 \pm 1$ \\
\hline & 2400 & $511 \pm 1$ & $514 \pm 3$ & $501 \pm 1$ & $509 \pm 4$ \\
\hline & 3000 & $544 \pm 1$ & $532 \pm 3$ & $513 \pm 1$ & $530 \pm 9$ \\
\hline \multirow[t]{3}{*}{$\mathrm{N}$} & 1900 & $15.4 \pm 0.6$ & $12.0 \pm 1.1$ & $9.1 \pm 0.7$ & $12.2 \pm 1.8$ \\
\hline & 2400 & $12.3 \pm 0.1$ & $9.1 \pm 1.0$ & $8.0 \pm 1.0$ & $9.8 \pm 1.3$ \\
\hline & 3000 & $10.4 \pm 0.6$ & $6.4 \pm 0.2$ & $4.9 \pm 0.4$ & $7.2 \pm 1.6$ \\
\hline \multirow[t]{3}{*}{$S$} & 1900 & $1.82 \pm 0.10$ & $1.40 \pm 0.09$ & $1.22 \pm 0.15$ & $1.48 \pm 0.18$ \\
\hline & 2400 & $1.18 \pm 0.14$ & $1.02 \pm 0.08$ & $0.88 \pm 0.09$ & $1.03 \pm 0.09$ \\
\hline & 3000 & $1.13 \pm 0.05$ & $0.87 \pm 0.08$ & $0.60 \pm 0.06$ & $0.87 \pm 0.15$ \\
\hline \multirow[t]{3}{*}{$\mathrm{P}$} & 1900 & $1.03 \pm 0.06$ & $0.85 \pm 0.19$ & $0.61 \pm 0.08$ & $0.83 \pm 0.12$ \\
\hline & 2400 & $0.57 \pm 0.09$ & $0.28 \pm 0.07$ & $0.29 \pm 0.06$ & $0.38 \pm 0.10$ \\
\hline & 3000 & $0.55 \pm 0.05$ & $0.26 \pm 0.02$ & $0.22 \pm 0.03$ & $0.34 \pm 0.10$ \\
\hline \multirow[t]{3}{*}{$\mathrm{K}$} & 1900 & $3.43 \pm 0.27$ & $5.09 \pm 0.75$ & $6.57 \pm 0.96$ & $5.03 \pm 0.91$ \\
\hline & 2400 & $1.99 \pm 0.09$ & $3.15 \pm 0.75$ & $4.31 \pm 0.87$ & $3.15 \pm 0.67$ \\
\hline & 3000 & $1.70 \pm 0.14$ & $2.13 \pm 0.29$ & $3.52 \pm 0.73$ & $2.45 \pm 0.55$ \\
\hline \multirow[t]{3}{*}{$\mathrm{Ca}$} & 1900 & $2.32 \pm 0.81$ & $2.35 \pm 0.59$ & $2.62 \pm 0.56$ & $2.43 \pm 0.10$ \\
\hline & 2400 & $2.14 \pm 0.41$ & $3.50 \pm 0.38$ & $5.65 \pm 2.32$ & $3.76 \pm 1.02$ \\
\hline & 3000 & $1.80 \pm 0.64$ & $3.88 \pm 0.54$ & $4.14 \pm 1.37$ & $3.27 \pm 0.74$ \\
\hline \multirow[t]{3}{*}{$\mathrm{Mg}$} & 1900 & $1.49 \pm 0.28$ & $1.32 \pm 0.19$ & $2.03 \pm 0.45$ & $1.61 \pm 0.23$ \\
\hline & 2400 & $0.94 \pm 0.04$ & $2.26 \pm 0.66$ & $1.27 \pm 0.23$ & $1.49 \pm 0.40$ \\
\hline & 3000 & $0.79 \pm 0.05$ & $1.06 \pm 0.14$ & $1.25 \pm 0.17$ & $1.03 \pm 0.13$ \\
\hline
\end{tabular}

${ }^{1}$ Simple mean is shown.

Table 4. Significance levels for differences in element concentrations in coarse roots $>5 \mathrm{~mm}$ in diameter of Graffenrieda emarginata from root diameter and altitude calculated by two-way ANOVA $(\mathrm{n}=3)$.

\begin{tabular}{lccccccc}
\hline & $\mathrm{C}$ & $\mathrm{N}$ & $\mathrm{S}$ & $\mathrm{P}$ & $\mathrm{K}$ & $\mathrm{Ca}$ & $\mathrm{Mg}$ \\
\hline Altitude & 0.619 & 0.664 & 0.302 & 0.540 & 0.114 & $<0.001$ & 0.262 \\
Diameter & 0.168 & 0.001 & 0.015 & 0.043 & 0.073 & 0.128 & 0.209
\end{tabular}

high $\mathrm{C}$ concentrations in mineral soil. In the upper $0.3 \mathrm{~m}$ of mineral soil, $\mathrm{C}$ concentrations were $7.7 \%$ at $1900 \mathrm{~m}$, $7.2 \%$ at $3000 \mathrm{~m}$, and only $1.6 \%$ at $2400 \mathrm{~m}$. The relative contribution of mineral soil and organic layer to soil carbon storage also differed between sites at different altitudes. At $1900 \mathrm{~m}$ and $3000 \mathrm{~m}$ more than $75 \%$ of total soil $\mathrm{C}$ was stored in mineral soil, whereas at $2400 \mathrm{~m}$ about $55 \%$ of total soil C was stored in mineral soil.

The contribution of plant biomass $\mathrm{C}$ in roots and shoots to total $\mathrm{C}$ stocks (C in plant biomass and soil) varied between $18 \%$ at $3000 \mathrm{~m}, 23 \%$ at $1900 \mathrm{~m}$ and $35 \%$ at $2400 \mathrm{~m}$. Thus, no consistent pattern with altitude became apparent (Table 7). The contribution of root $\mathrm{C}$ stocks to

Table 5. Element concentrations $\left(\mathrm{mg} \mathrm{g}^{-1}\right)$ in coarse roots $>5 \mathrm{~mm}$ in diameter of Graffenrieda emarginata $(\mathrm{n}=3)$. Data are mean \pm SE.

\begin{tabular}{|c|c|c|c|c|c|c|}
\hline \multirow[b]{2}{*}{ Element } & \multirow{2}{*}{$\begin{array}{l}\text { Altitude } \\
\text { (m) }\end{array}$} & \multicolumn{5}{|c|}{ Diameter class $(\mathrm{mm})$} \\
\hline & & $>5-10$ & $>10-20$ & $>20-50$ & $>50$ & Mean $^{1}$ \\
\hline \multirow[t]{2}{*}{$\mathrm{C}$} & 1900 & $495 \pm 1$ & $491 \pm 4$ & $490 \pm 1$ & $486 \pm 2$ & $490 \pm 2$ \\
\hline & 2400 & $490 \pm 4$ & $491 \pm 3$ & $488 \pm 1$ & $488 \pm 1$ & $489 \pm 1$ \\
\hline \multirow[t]{2}{*}{$\mathrm{N}$} & 1900 & $4.3 \pm 0.4$ & $4.6 \pm 1.4$ & $2.3 \pm 0.2$ & $2.4 \pm 0.1$ & $3.4 \pm 0.6$ \\
\hline & 2400 & $5.2 \pm 0.3$ & $3.0 \pm 0.3$ & $2.6 \pm 0.1$ & $2.1 \pm 0.1$ & $3.2 \pm 0.7$ \\
\hline \multirow[t]{2}{*}{$S$} & 1900 & $0.70 \pm 0.04$ & $0.72 \pm 0.26$ & $0.33 \pm<0.01$ & $0.31 \pm 0.01$ & $0.51 \pm 0.11$ \\
\hline & 2400 & $0.76 \pm 0.28$ & $0.33 \pm 0.01$ & $0.30 \pm 0.02$ & $0.26 \pm 0.01$ & $0.41 \pm 0.12$ \\
\hline \multirow[t]{2}{*}{$\mathrm{P}$} & 1900 & $0.081 \pm 0.012$ & $0.086 \pm 0.033$ & $0.040 \pm 0.005$ & $0.037 \pm 0.002$ & $0.061 \pm 0.013$ \\
\hline & 2400 & $0.087 \pm 0.012$ & $0.042 \pm 0.001$ & $0.033 \pm<0.001$ & $0.056 \pm 0.026$ & $0.054 \pm 0.012$ \\
\hline \multirow[t]{2}{*}{ K } & 1900 & $3.0 \pm 0.2$ & $3.2 \pm 0.7$ & $2.0 \pm 0.1$ & $1.9 \pm 0.1$ & $2.5 \pm 0.3$ \\
\hline & 2400 & $4.5 \pm 1.0$ & $2.4 \pm 0.1$ & $2.5 \pm 0.4$ & $3.2 \pm 0.7$ & $3.2 \pm 0.5$ \\
\hline \multirow[t]{2}{*}{$\mathrm{Ca}$} & 1900 & $9.2 \pm 0.8$ & $15.7 \pm 6.9$ & $6.8 \pm 1.1$ & $7.7 \pm 0.3$ & $9.9 \pm 2.0$ \\
\hline & 2400 & $11.8 \pm 0.8$ & $12.5 \pm 0.9$ & $13.2 \pm 1.4$ & $18.8 \pm 3.1$ & $14.1 \pm 1.6$ \\
\hline \multirow[t]{2}{*}{$\mathrm{Mg}$} & 1900 & $0.78 \pm 0.40$ & $0.22 \pm 0.05$ & $0.23 \pm 0.04$ & $0.66 \pm 0.24$ & $0.47 \pm 0.14$ \\
\hline & 2400 & $0.43 \pm 0.21$ & $0.35 \pm 0.04$ & $0.24 \pm 0.01$ & $0.26 \pm 0.04$ & $0.32 \pm 0.04$ \\
\hline
\end{tabular}

\footnotetext{
${ }^{1}$ Simple mean is shown.
} 
Table 6. Element stocks $\left(\mathrm{g} \mathrm{m}^{-2}\right)$ in fine roots $\leq 2 \mathrm{~mm}$ in diameter $(\mathrm{n}=5)$ and coarse roots $>2 \mathrm{~mm}$ in diameter from Ecuadorian montane forests and data from other tropical forests. Different lower-case letters indicate significant differences in nutrient stocks between altitudes (Tukey test, $\mathrm{P}<0.05)$.

\begin{tabular}{|c|c|c|c|c|c|c|c|c|}
\hline \multirow[b]{2}{*}{ Root fraction } & \multirow{2}{*}{$\begin{array}{l}\text { Altitude } \\
(\mathrm{m})\end{array}$} & \multicolumn{7}{|c|}{ Element stocks $\left(\mathrm{g} \mathrm{m}^{-2}\right)$} \\
\hline & & $\mathrm{C}$ & $\mathrm{N}$ & S & $\mathrm{P}$ & K & $\mathrm{Ca}$ & $\mathrm{Mg}$ \\
\hline \multirow[t]{3}{*}{ Fine roots } & 1900 & $431^{\mathrm{b}}$ & $12.0^{\mathrm{a}}$ & $1.42^{\mathrm{a}}$ & $0.82^{\mathrm{a}}$ & $3.49^{\mathrm{a}}$ & $1.99^{\mathrm{a}}$ & $1.53^{\mathrm{a}}$ \\
\hline & 2400 & $379^{c}$ & $8.1^{\mathrm{b}}$ & $0.82^{\mathrm{b}}$ & $0.33^{\mathrm{c}}$ & $1.83^{\mathrm{b}}$ & $2.01^{\mathrm{a}}$ & $0.81^{b}$ \\
\hline & 3000 & $680^{\mathrm{a}}$ & $11.2^{\mathrm{a}}$ & $1.31^{\mathrm{a}}$ & $0.55^{\mathrm{b}}$ & $2.34^{\mathrm{b}}$ & $3.24^{\mathrm{a}}$ & $1.12^{\mathrm{ab}}$ \\
\hline \multirow[t]{3}{*}{ Coarse roots $^{1}$} & 1900 & 938 & 8.6 & 1.18 & 0.31 & 6.69 & 19.40 & 1.27 \\
\hline & 2400 & 1621 & 12.7 & 1.64 & 0.29 & 9.75 & 36.21 & 1.63 \\
\hline & 3000 & 2630 & 17.9 & 2.39 & 0.38 & 14.70 & 54.21 & 4.19 \\
\hline \multirow{3}{*}{$\begin{array}{l}\text { Total root } \\
\text { biomass }^{1}\end{array}$} & 1900 & 1369 & 20.6 & 2.60 & 1.13 & 10.18 & 21.40 & 2.81 \\
\hline & 2400 & 1999 & 20.8 & 2.46 & 0.62 & 11.58 & 38.22 & 2.44 \\
\hline & 3000 & 3310 & 29.1 & 3.70 & 0.93 & 17.04 & 57.45 & 5.31 \\
\hline \multirow[t]{7}{*}{$\begin{array}{l}\text { Total root } \\
\text { biomass }\end{array}$} & $\begin{array}{l}\text { Lower } \\
\text { montane }\end{array}$ & & & & & & & \\
\hline & New Guinea ${ }^{2}$ & - & 13.7 & - & 0.6 & 18.6 & 33.3 & 6.1 \\
\hline & Puerto Rico ${ }^{2}$ & - & 30.0 & - & 1.6 & 23.0 & 30.0 & 8.5 \\
\hline & Lowland & & & & & & & \\
\hline & Brazil $^{3}$ & - & 55.3 & - & 0.7 & 6.2 & 8.3 & 5.5 \\
\hline & Ghana $^{2}$ & - & 32.6 & - & 2.4 & 14.3 & 26.8 & 6.5 \\
\hline & Brazil $^{4}$ & $1023-1260$ & $11-40$ & - & $0.3-1.1$ & - & - & - \\
\hline
\end{tabular}

${ }^{1}$ Data are estimated with help of element concentrations in coarse root biomass of Graffenrieda emarginata.

${ }^{2}$ From Edwards \& Grubb (1982).

${ }^{3}$ From Klinge (1975).

${ }^{4}$ From Silver et al. (2000).

Table 7. Carbon stocks in soil $(n=5)$ and contribution of soil, shoot and roots to total carbon stocks at different altitudes of Ecuadorian montane forests. Data shown are mean \pm SE. Different lower-case letters indicate significant differences between altitudes (Tukey test, $\mathrm{P}<0.05$ ).

\begin{tabular}{ccccc}
\hline & & \multicolumn{3}{c}{$\begin{array}{c}\text { Relative contribution to total } \\
\text { carbon stocks }(\%)\end{array}$} \\
\cline { 3 - 5 } $\begin{array}{c}\text { Altitude } \\
(\mathrm{m})\end{array}$ & $\begin{array}{c}\text { Soil C stocks } \\
\left(\mathrm{g} \mathrm{m}^{-2}\right)\end{array}$ & Soil & Shoots $^{1}$ & Roots \\
\hline 1900 & $34200 \pm 4100^{\mathrm{a}}$ & 77 & 20 & 3 \\
2400 & $13100 \pm 400^{\mathrm{b}}$ & 65 & 25 & 10 \\
3000 & $40200 \pm 8200^{\mathrm{a}}$ & 82 & 11 & 7 \\
\hline
\end{tabular}

${ }^{1}$ Carbon stocks in shoot biomass are derived from shoot biomass data (G. Moser, pers. comm.), assuming $500 \mathrm{mg} \mathrm{g}^{-1}$ as average C concentration in biomass (Gordon \& Jackson 2000, Wilcke et al. 2005).

total plant $\mathrm{C}$ stocks increased with increasing altitude from $14 \%$ at $1900 \mathrm{~m}$ to $29 \%$ at $2400 \mathrm{~m}$ and $38 \%$ at $3000 \mathrm{~m}$.

\section{DISCUSSION}

\section{Impact of altitude on root biomass}

Fine- and coarse-root biomass was substantially higher at $3000 \mathrm{~m}$ than at 1900 and $2400 \mathrm{~m}$. This is in agreement with results of Röderstein et al. (2005) obtained from the same study sites for fine roots down to a soil depth of $0.2 \mathrm{~m}$. It is worth mentioning that absolute amounts of coarse-root biomass may be somewhat underestimated by our approach because very high coarse-root densities occurred underneath the stem bases where sampling was not possible.
The absolute increase of total root biomass with increasing altitude was accompanied by increased biomass partitioning to roots at high altitudes (Table 1). It is well documented that biomass partitioning between above- and below-ground organs is dependent on environmental conditions, such as light intensity (Sultan 2003), soil moisture content (Bell \& Sultan 1999), root zone temperature (Engels 1993) and wind speeds (Cordero 1999). Theoretically, biomass partitioning is regulated by plants to optimize capture of aboveground and below-ground resources (Farrar \& Jones 2003, McConnaughay \& Coleman 1999). Environmental conditions leading to growth limitation by water and mineral nutrients should increase biomass partitioning to roots whereas environmental conditions leading to growth limitation by photosynthesis should increase allocation to shoots. At high altitudes, capture of belowground resources may be reduced, e.g. due to soil nutrient availability (Bruijnzeel et al. 1993, Edwards \& Grubb 1977, Tanner et al. 1998) and low nutrient uptake ability of roots due to low oxygen availability in soil (Bruijnzeel \& Veneklaas 1998). Capture of above-ground resources may be reduced by increased cloudiness, i.e. low light intensity (Bruijnzeel \& Veneklaas 1998) and low photosynthetic activity of leaves due to low air temperatures (Kitayama \& Aiba 2002). According to the theory of functional equilibrium between roots and shoots (Brouwer 1983), increased biomass partitioning to roots at high altitudes would indicate that environmental conditions at high altitudes limit nutrient uptake activity 
more than photosynthetic activity. In accordance with this conclusion, nutrient concentrations in fine roots (Table 3) and foliar nitrogen concentrations of trees were substantially lower at high $\left(11.3 \mathrm{mg} \mathrm{g}^{-1}\right.$ at $\left.3000 \mathrm{~m}\right)$ in comparison with low altitudes $\left(21.7 \mathrm{mg} \mathrm{g}^{-1}\right.$ at $\left.1900 \mathrm{~m}\right)$. Furthermore, stem concentrations of non-structural carbohydrates were generally high and similar at $1900 \mathrm{~m}$

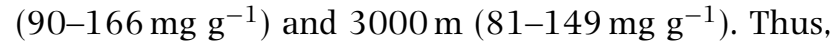
there was no evidence for a deficiency in $\mathrm{C}$ supply at high altitude.

The proportion of coarse roots to fine roots was higher at 2400 and $3000 \mathrm{~m}$ in comparison to $1900 \mathrm{~m}$ (Table 1). This was associated with a significant increase in coarseroot biomass and an increase of coarse root to shoot ratios from $0.11: 1$ at $1900 \mathrm{~m}$ to $0.33: 1$ at $2400 \mathrm{~m}$ and $0.48: 1$ at $3000 \mathrm{~m}$. Cordero (1999) as well as Henry \& Thomas (2002) observed that in tree saplings and annual species, root to shoot ratios were increased by exposure to wind. Since tree anchorage is mainly provided by coarse roots (Robinson et al. 2003) increased allocation to coarse root biomass may be an indication of increased mechanical stress. In comparison to lower altitudes, mechanical stress at $3000 \mathrm{~m}$ was increased by high wind speeds and hampered deep rooting, possibly as a result of oxygen deficiency and shallow mineral soils (Soethe et al. 2006a, b). Potential root soil plates were always shallow at this altitude and coarse root systems exhibited a large range of traits that were supposed to improve anchorage, such as marked root system asymmetry and stilt roots (Soethe et al. 2006a). There is evidence that increased belowground biomass at high altitudes is at least partly a response to increased mechanical stress.

\section{Contribution of soil and plant biomass to $C$ sequestration}

Soil C stocks at $2400 \mathrm{~m}$ (Table 7) were slightly higher than the average of tropical forests $\left(12300 \mathrm{~g} \mathrm{~m}^{-2}\right)$ given in the review of Malhi et al. (1999). Soil C stocks at $3000 \mathrm{~m}$ even exceeded average $C$ stocks in boreal forests $\left(34300 \mathrm{~g} \mathrm{~m}^{-2}\right.$; Mahli et al. 1999), emphasizing the high potential for $C$ sequestration of tropical montane forest soils. However, no consistent impact of altitude on soil $\mathrm{C}$ stocks became apparent.

The contribution of biomass $\mathrm{C}$ to total $\mathrm{C}$ stocks (soil plus biomass) varied between $18 \%$ at $3000 \mathrm{~m}$ and $35 \%$ at $2400 \mathrm{~m}$ (Table 7). This is somewhat lower than in a tropical montane forest in New Guinea (29-41\%) reported by Edwards \& Grubb (1977). In a global comparison, the $\mathrm{C}$ distribution between plant biomass and soil at least at $1900 \mathrm{~m}$ and $3000 \mathrm{~m}$ was more similar to $\mathrm{C}$ distribution in boreal forests where most C (about 84\%) is stored in soil organic matter than to $\mathrm{C}$ distribution in tropical lowland forests, where about half the $\mathrm{C}$ is stored in biomass (Dixon et al. 1994, Malhi et al. 1999). However, no consistent effect of altitude on carbon stocks in the plant biomass or the contribution of plant biomass $\mathrm{C}$ to total C (soil plus biomass) became apparent.

Carbon stocks in the root biomass increased with increasing altitude (Table 6). At $3000 \mathrm{~m}$ root C stocks were about three times higher than those reported by Silver et al. (2000) for lowland tropical forests. Furthermore, the contribution of roots to total plant $\mathrm{C}$ stocks continuously increased with increasing altitude. However, irrespective of altitude, the contribution of roots to total C sequestration in the forest ecosystem was small (Table 7).

\section{The impact of altitude on nutrient stocks in roots}

Fine-root biomass as well as stocks of N, P and Mg stored in fine-root biomass were similar to a tropical lowland forest (Klinge 1975; biomass: 1613, N: 13.7, P: 0.24, $\mathrm{Mg}: 0.86 \mathrm{~g} \mathrm{~m}^{-2}$ ) whereas stocks of $\mathrm{K}$ and $\mathrm{Ca}$ in fine roots (Table 6) were several times higher than in the tropical lowland forest (Klinge 1975; $\mathrm{K}: 0.6 \mathrm{~g} \mathrm{~m}^{-2}$, Ca: $0.5 \mathrm{~g} \mathrm{~m}^{-2}$ ). In contrast to the significantly increased fine-root biomass at high in comparison to low altitudes, nutrient stocks in fine roots showed no consistent pattern of change with increasing altitude. This was due to a decrease in the concentrations of $\mathrm{N}, \mathrm{S}, \mathrm{P}, \mathrm{K}$ and $\mathrm{Mg}$ in fine roots with increasing altitude (Table 3), counteracting the increase in nutrient stocks by increasing biomass. In general, nutrient concentrations in roots $\leq 5 \mathrm{~mm}$ in diameter lay within the range of those reported by Priess et al. (1999) for two submontane tropical forest stands and one cloud forest stand in Venezuela and one montane rain forest stand in New Guinea (N: 7.4-14.1, P: 0.33-0.50, K: 2.45.0, Ca: $1.1-7.3, \mathrm{Mg}: 1.3-6.1 \mathrm{mg} \mathrm{g}^{-1}$ ). As an exception, concentrations of $\mathrm{P}$ at $1900 \mathrm{~m}$ markedly exceeded these ranges.

Decreasing root $\mathrm{N}$ concentration with increasing altitude was also detected in different grass species growing in New Zealand between 45 and $1205 \mathrm{~m}$ (Craine \& Lee 2003). The authors suggested that the decrease in $\mathrm{N}$ concentrations with increasing altitude could be attributed to a decrease in nutrient availability. Accordingly, Ostertag \& Hobbie (1999) observed lower P concentrations in fine roots at a P-deficient site than at a site with sufficient $P$ supply in a tropical montane forest in Hawaii. Our own unpublished data showing a consistent pattern of decreasing foliar nutrient concentrations with increasing altitude also suggest that the decrease in nutrient concentrations in root tissue with increasing altitude was mainly caused by nutrient deficiency.

In contrast to nutrient stocks in fine-root biomass, estimated nutrient stocks in total root biomass followed the increase in root biomass with increasing altitude (Table 6). This was due to the absence of an impact of altitude on nutrient concentrations in coarse roots of G. emarginata. The calculation of nutrient stocks in coarse root biomass at all altitudes with average nutrient concentrations from $1900 \mathrm{~m}$ and $2400 \mathrm{~m}$ seems justified 
because in this root pool concentrations of all elements except Ca were not dependent on altitude. However, for Ca this procedure may lead to a slight overestimation of stocks at $1900 \mathrm{~m}$ and to a slight underestimation at higher altitude, because the significant increase in Ca concentrations with increasing altitude is not considered.

The impact of environmental conditions on nutrient concentrations in coarse roots is poorly understood. Differences in the impact of altitude on nutrient concentrations in fine- and coarse-root biomass in the present study may either be caused by the differences in the methodological approaches or may indicate that nutrient concentrations in coarse-root biomass are less sensitive to changes of environmental conditions than nutrient concentrations in fine roots.

The contribution of fine- and coarse-root biomass to element storage in total root biomass varied considerably between nutrients (Table 6). Considerable proportions (33.3-72.7\%) of total root $\mathrm{N}, \mathrm{S}$ and $\mathrm{P}$ were stored in fine-root biomass $<2 \mathrm{~mm}$ in diameter, but only small proportions of Ca (between 5.3 and 9.3\%). This implies that in the present study large proportions of root N, S and $\mathrm{P}$ were included in short-term nutrient cycling, i.e. these nutrients were returned to the soil within a few years, whereas most $\mathrm{Ca}$ in roots was immobilized in the long term.

\section{CONCLUSIONS}

Higher root biomass at higher than at lower altitudes reflected the increased allocation of biomass to the root system, presumably as a response to decreased nutrient availability in soil and high mechanical stress affecting trees growing at high altitudes. Higher $\mathrm{C}$ and nutrient stocks in coarse roots at higher than at lower altitudes suggest that the importance of this root fraction for long-term nutrient accumulation is increased at high altitudes. Due to the response of nutrient concentrations in fine roots to the change of environmental conditions such as soil nutrient availability along the altitudinal gradient, nutrient stocks in this root fraction did not follow the marked increase of root biomass with increasing altitude. Root biomass of this tropical montane forest may contribute significantly to short-term nutrient cycling by fine-root turnover. However, the contribution of root biomass to $\mathrm{C}$ sequestration within this forest is rather low.

\section{ACKNOWLEDGEMENTS}

We are grateful to Narcisa Urgiles, Ruth Poma, Letti Jimbo, Sascha Vrecar and Carmen Wolfram-Wienberg for field and laboratory assistance. We thank INEFAN for granting the research permit and the Fundacion Científica San Francisco for logistic support at the ECSF. We gratefully acknowledge financial support supplied by the Deutsche Forschungsgemeinschaft (En342/5).

\section{LITERATURE CITED}

BARRON-GAFFORD, G. A., WILL, R. E., BURKES, E. C., SHIVER, B. \& TESKEY, R. O. 2003. Nutrient concentrations and contents, and their relation to stem growth, of intensively managed Pinus taeda and Pinus elliotii stands of different planting densities. Forest Science 49:291-300.

BELL, D. L. \& SULTAN, S. E. 1999. Dynamic phenotypic plasticity for root growth in Polygonum: a comparative study. American Journal of Botany 86:807-819.

BROUWER, R. 1983. Functional equilibrium: sense or nonsense. Netherlands Journal of Agricultural Science 31:335-348.

BRUIJNZEEL, L. A. \& VENEKLAAS, E. J. 1998. Climatic conditions and tropical montane forest productivity: the fog has not lifted yet. Ecology 79:3-9.

BRUIJNZEEL, L. A., WATERLOO, M. J., PROCTOR, J., KUITERS, A. T. \& KOTTERINK, B. 1993. Hydrological observations in montane rain forests on Gunung Silam, Sabah, Malaysia, with special reference to the "Massenerhebung" effect. Journal of Ecology 81:145-167.

CHAVE, J., ANDALO, C., BROWN, S., CAIRNS, M. A., CHAMBERS, J. Q., EAMUS, D., FOLSTER, H., FROMARD, F., HIGUCHI, N., KIRA, T., LESCURE, J. P., NELSON, B. W., OGAWA, H., PUIG, H., RIERA, B. \& YAMAKURA, T. 2005. Tree allometry and improved estimation of carbon stocks and balance in tropical forests. Oecologia 145: 87-99.

CHEN, H., HARMON, M. E. \& GRIFFITHS, R. P. 2001. Decomposition and nitrogen release from decomposing woody roots in coniferous forests of the Pacific Northwest: a chronosequence approach. Canadian Journal of Forest Research 31:246-260.

CLARK, D. A. 2002. Are tropical forests an important carbon sink? Reanalysis of the long-term plot data. Ecological Applications 12:3-7. CLARK, D. A. 2004. Tropical forests and global warming: slowing it down or seeding it up? Frontiers in Ecology 2:73-80.

CORDERO, R. A. 1999. Ecophysiology of Cecropia schreberiana saplings in two wind regimes in an elfin cloud forest: growth, gas exchange, architecture and stem biomechanics. Tree Physiology 19:153-163.

CRAINE, J. M. \& LEE, W. G. 2003. Covariation in leaf and root traits for native and non-native grasses along an altitudinal gradient in New Zealand. Oecologia 134:471-478.

DIXON, R. K., BROWNS, S., HOUGHTON, R. A., SOLOMON, A. M., TREXLER, M. C. \& WISNIEWSKI, J. 1994. Carbon pools and flux of global forest ecosystems. Science 263:185-190.

EDWARDS, P. J. \& GRUBB, P. J. 1977. Studies of mineral cycling in a montane rain forest in New Guinea. I. The distribution of organic matter in the vegetation and soil. Journal of Ecology 65:943-969.

EDWARDS, P. J. \& GRUBB, P. J. 1982. Studies of mineral cycling in a montane rain forest in New Guinea. IV. Soil characteristics and the division of mineral elements between vegetation and soil. Journal of Ecology 70:649-666.

ENGELS, C. 1993. Differences between maize and wheat in growthrelated nutrient demand and uptake of potassium and phosphorus at suboptimal root zone temperatures. Plant and Soil 150:129-138.

FABIAN, P., KOHLPAINTNER, M. \& ROLLENBECK, R. 2005. Biomass burning in the Amazon - fertilizer for the mountainous rain forest in Ecuador. Environmental Science and Pollution Research 12:290296. 
FARRAR, J. D. \& JONES, D. L. 2003. The control of carbon acquisition by and growth of roots. Pp. 91-124 in de Kroon, H. \& Visser, E. J. W. (eds.). Root ecology. Springer Verlag, Berlin.

FEHSE, J., HOFSTEDE, R., AGUIRRE, N., PALADINES, C., KOOIJMAN, A. \& SEVINK, J. 2002. High altitude tropical secondary forests: a competitive carbon sink? Forest Ecology and Management 163: 9-25.

GORDON, W. S. \& JACKSON, R. B. 2000. Nutrient concentrations in fine roots. Ecology 81:275-280.

GUEVARA, R. \& ROMERO, I. 2004. Spatial and temporal abundance of mycelial mats in the soil of a tropical rain forest in Mexico and their effects on the concentration of mineral nutrients in soils and fine roots. New Phytologist 163:361-370.

HEINRICHS, H., BRUMSACK, H. J., LOFTFIELD, N. \& KÖNIG, N. 1986. Verbessertes Druckaufschlusssystem für biologische und anorganische Materialien. Zeitschrift für Pflanzernährung und Bodenkunde 149:350-353.

HENDRICKS, J. J., ABER, J. D., NADELHOFFER, K. J. \& HALLETT, R. D. 2000. Nitrogen controls on fine root substrate quality in temperate forest ecosystems. Ecosystems 3:57-69.

HENRY, H. A. L. \& THOMAS, S. C. 2002. Interactive effects of lateral shade and wind on stem allometry, biomass allocation, and mechanical stability in Abutilon theophrasti (Malvaceae). American Journal of Botany 89:1609-1615.

HOLDER, C. D. 2003. Fog precipitation in the Sierra de las Minas Biosphere Reserve, Guatemala. Hydrological Process 17:2001-2010.

JANISCH, J. E., HARMON, M. E., CHEN, H., FASTH, B. \& SEXTON, J. 2005. Decomposition of coarse woody debris originating by clearcutting of an old-growth conifer forest. Ecoscience 12:151-160. JOHN, B., PANDEY, H. N. \& TRIPATHI, R. S. 2002. Decomposition of fine roots of Pinus kesiya and turnover of organic matter, $\mathrm{N}$ and $\mathrm{P}$ of coarse and fine pine roots and herbaceous roots and rhizomes in subtropical pine forest stands of different ages. Biology and Fertility of Soils 35:238-246.

JORDAN, C. F. 1985. Nutrient cycling in tropical forest ecosystems. John Wiley \& Sons, Chichester. 190 pp.

JOSLIN, J. D. \& HENDERSON, G. S. 1987. Organic matter and nutrients associated with fine root turnover in a white oak stand. Forest Science 33:330-346.

KITAYAMA, K. \& AIBA, S. I. 2002. Ecosystem structure and productivity of tropical rain forests along altitudinal gradients with contrasting soil phosphorus pools on Mount Kinabalu, Borneo. Journal of Ecology 90:37-51.

KLINGE, H. 1975. Root mass estimation in lowland tropical rain forests of central Amazonia, Brazil. III. Nutrients in fine roots from giant humus podsols. Tropical Ecology 16:28-38.

MALHI, Y., BALDOCCHI, D.D.\&JARVIS, P.G. 1999. The carbon balance of tropical, temperate and boreal forests. Plant Cell and Environment 22:715-740.

MARRS, R. H., PROCTOR, J., HEANEY, A. \& MOUNTFORD, M. D. 1988. Changes in soil nitrogen-mineralization and nitrification along an altitudinal transect in a tropical rain forest in Costa Rica. Journal of Ecology 76:466-482.

MCCLAUGHTERY, C. A., ABER, J. D. \& MELILLO, J. M. 1982. The role of fine roots in the organic matter and nitrogen budgets of two forested ecosystems. Ecology 63:1481-1490.
MCCONNAUGHAY, K.D. M. \& COLEMAN, J. S. 1999. Biomass allocation in plants:ontogeny or optimality? A test along three resource gradients. Ecology 80:2581-2593.

MEIER, C. E., GRIER, C. C. \& COLE, D. W. 1985. Below- and aboveground $\mathrm{N}$ and $\mathrm{P}$ use by Abies amabilis stands. Ecology 66:1928-1942.

MURPHY, J. \& RILEY, J. P. 1962. A modified single solution method for phosphate in natural waters. Analytica Chimica Acta 12:162-176.

NAMBIAR, E. K. S. 1987. Do nutrients retranslocate from fine roots? Canadian Journal of Forest Research 17:913-918.

OSTERTAG, R. 2001. Effects of nitrogen and phosphorus availability on fine-root dynamics in Hawaiian montane forests. Ecology 82:485499.

OSTERTAG, R. \& Hobbie, S. E. 1999. Early stages of root and leaf decomposition in Hawaiian forests: effects of nutrient availability. Oecologia 121:564-573.

PERSSON, H. 1978. Root dynamics in a young Scots pine stand in Central Sweden. Oikos 30:508-519.

PRIESS, J., THEN, C.\& FÖLSTER, H. 1999. Litter and fine-root production in three types of tropical premontane rain forest in SE Venezuela. Plant Ecology 143:171-187.

RAICH, J. W. \& NADELHOFFER, K. J. 1989. Belowground carbon allocation in forest ecosystems: global trends. Ecology 70:1346-1354.

ROBINSON, D., HODGE, A. \& FITTER, A. 2003. Constraints on the form and function of root systems. Pp. 1-60 in de Kroon, H. \& Visser, E. J. W. (eds.). Root ecology. Springer Verlag, Berlin.

RÖDERSTEIN, M., HERTEL, D. \& LEUSCHNER, C. 2005. Above- and below-ground litter production in three tropical montane forests in southern Ecuador. Journal of Tropical Ecology 21:483-492.

SILVER, W. L., NEFF, J., MCGRODDY, M., VELDKAMP, E., KELLER, M. \& COSME, R. 2000. Effects of soil texture on belowground carbon and nutrient storage in a lowland Amazonian forest ecosystem. Ecosystems 3:193-209.

SOETHE, N., LEHMANN, J. \& ENGELS, C. 2006a. Root morphology and anchorage of six native tree species from a tropical montane forest and an elfin forest in Ecuador. Plant and Soil 279:173-185.

SOETHE, N., LEHMANN, J. \& ENGELS, C. 2006b. The vertical pattern of rooting and nutrient uptake at different altitudes of a south Ecuadorian montane forest. Plant and Soil 286:287-299.

SULTAN, S. E. 2003. Phenotropic plasticity in plants: a case study in ecological development. Evolution and Development 5:25-33.

TANNER, E. V. J., VITOUSEK, P. M. \& CUEVAS, E. 1998. Experimental investigation of nutrient limitation of forest growth on wet tropical mountains. Ecology 79:10-22.

VANCE, E. D. \& NADKARNI, N. M. 1992. Root mass distribution in a moist tropical montane forest. Plant and Soil 142:31-39.

VOGT, K. A., VOGT, D. J., PALMIOTTO, P. A., BOON, P., O’HARA, J. \& Asbjornsen, H. 1996. Review of root dynamics in forest ecosystems grouped by climate, climatic forest type and species. Plant and Soil 187:159-219.

WILCKE, W., HESS, T., BENGEL, C., HOMEIER, J., VALAREZO, C.\&ZECH, W. 2005. Coarse woody debris in a montane forest in Ecuador: mass, $\mathrm{C}$ and nutrient stock, and turnover. Forest Ecology and Management 205:139-147.

YIN, X. \& PERRY, J. 1991. Factors affecting nitrogen concentration of fine roots in forest communities: regression analysis of literature data. Forest Science 37:374-382. 